\title{
PENINGKATKAN KETERAMPILAN MENULIS TEKS EKSPOSISI MENGGUNAKAN METODE TAKE AND GIVE DENGAN PEMANFAATAN STRATEGI 3W2H
}

\author{
Yerry Mijianti, Endah Puji Puspitosari \\ Universitas Muhammadiyah Jember \\ yerry.mijianti@unmuhjember.ac.id \\ Diterima: 24 Oktober 2018 \\ Publikasi: 27 Februari 2019 \\ DOI: http://dx.doi.org/10.32528/bb.v4i1.1873
}

\begin{abstract}
ABSTRAKS
Masalah dalam penelitian inibagaimanakah proses belajar menulis teks eksposisi dan hasil belajar menulis teks eksposisi melalui metode take and give dengan pemanfaatan strategi $3 \mathrm{~W} 2 \mathrm{H}$ pada Kelas X IPA 1 SMA Muhammadiyah 3 Jember. Penelitian ini bertujuan mendeskripsikan proses belajar menulis teks eksposisi dan hasil belajar menulis teks eksposisi melalui metode take and give dengan pemanfaatan strategi 3 W2H pada Kelas XIPA 1 SMA Muhammadiyah 3 Jember. Penelitian Tindkan Kelas ini meggunakan desain penelitian menurut Arikunto dengan dua siklus. Subjek penelitian adalah siswa kelas XIPA 1 yang berjumlah 21 siswa. Lokasi penelitian di SMA Muhammadiyah Jember. Prosedur penelitian terdiri dari empat tahap, yaitu tahap perencanaan, tahap tindakan, tahap observasi, dan tahap refleksi. Penelitian tindakan kelas sukses atau berhasil apabila nilai siswa lebih besar atau sama dengan nilai 87, dan secara klaksikal jumlah siswa yang mendapat nilai sesuai kritreria ketuntasan mencapai 19-21 siswa. Instrumen penelitian meliputi instrument tes, lembar observasi, dan angket siswa. Proses belajar siswa semakin meningkat dari pretes $(2,375)$, siklus $1(3,408)$, dan siklus $2(4,618)$. Hasil belajar siswa semakin meningkat dari prasiklus (83,19), siklus 1 (99,19), dan siklus $2(104,57)$.

Kata Kunci: menulis, teks eksposisi, take and give, $3 \mathrm{~W} 2 \mathrm{H}$
\end{abstract}

\begin{abstract}
ABSTRACS
The problem in this study is the process of learning to write exposition text and the results of learning to write exposition text through the take and give method with the use of $3 \mathrm{~W} 2 \mathrm{H}$ strategies in Class XIPA 1 Muhammadiyah 3 High School in Jember. This study aims to describe the process of learning to write exposition text and the results of learning to write exposition text through the take and give method with the use of 3W2H strategies in Class X IPA 1 Muhammadiyah 3 Jember High School. Piercing Research This class uses research designs according to Arikunto with two cycles. The research subjects were students of class X IPA 1 totaling 21 students. Research location at Muhammadiyah Jember High School. The research procedure consists of four stages, namely the planning stage, the action stage, the observation phase, and the reflection stage. Classroom action research is successful or successful if the student's score is greater or equal to 87, and the number of students who score according to the criteria of completeness reaches 19-21 students. The research instruments included test instruments, observation sheets, and student questionnaires. Student learning process is increasing from pretest $(2,375)$, cycle $1(3,408)$, and cycle $2(4,618)$. Student learning outcomes are increasing from pre-cycle $(83,19)$, cycle $1(99,19)$, and cycle 2 (104,57).
\end{abstract}

Keywords: writing, exposition text, take and give, $3 \mathrm{~W} 2 \mathrm{H}$ 


\section{PENDAHULUAN}

Memiliki pengetahuan tentang teks ekposisi dan terampil menulis teks eksposisi merupakan tuntutan dari kompetensi dasar menulis teks ekposisi pada pelajaran Bahasa Indinesa kelas X. Hal ini membuat siswa kelas $X$ harus mampu menghasilkan sebuah tulisan berbentuk teks eksposisi. Siswa kelas X IPA 1 SMA Muhammadiyah Jember telah memiliki keduanya. Namun, terdapat beberapa siswa yang kesulitan menyusun teks ekposisi.Siswa tersebut kurang aktif dalam Kegiatan Belajar Mengajar (KBM). Pernyataan tersebut dibuktikan dengan nilai pretes menulis teks ekposisi yang menunjukkan angka di bawah 87 yaitu di bawah kriteria ketuntasan.

Masalah tersebut diperbaiki dengan penerapan metode pembelajaran take and give serta menggunakan strategi $3 \mathrm{~W} 2 \mathrm{H}$. Metode pembelajaran take and give ini diharapkan dapat meningkatkan kemampuan siswa dalam menulis teks ekposisi. Metode ini adalah salah satu metode pembelajaran yang terdapat pada model pembelajaran kooperatif atau cooperative learning. Metode ini mengandalkan penguasaan materi melalui kartu, keterampilan bekerja berpasangan, dan berbagi informasi. Aktivitas pembelajaran pada metode Take and Give ini membuat seluruh siswa terlibat aktif. Oleh karena itu, tidak ditemukan lagi siswa yang pasif pada kegiatan pembelajaran.

Metode penguasan pengetahuan dengan take and give dikolaborasikan dengan strategi $3 \mathrm{~W} 2 \mathrm{H}$ dalam pembelajaran menulis teks ekposisi. Alasan penulis menggunakan strategi $3 \mathrm{~W} 2 \mathrm{H}$ adalah untuk meningkatkan kemampuan siswa dalam menulis teks ekposisi. Pada penelitian ini strategi $3 \mathrm{~W} 2 \mathrm{H}$ dapat membantu siswa dalam mengatasi kesulitan memunculkan ide tulisan. Dengan menggunakan strategi tersebut diharapkan dapat membuat siswa memunculkan pertanyaan-pertanyaan yang akan dicari jawabannya dalam kegiatan pembelajaran menulis teks eksposisi. Dalam hal ini, siswa diharapkan lebih terencana dan mudah memunculkan gagasan menulis.

Berdasarkan latar belakang di atas, masalah yang ingin dicari jalan keluarnya yaitu: (1)Bagaimanakah proses belajar menulis teks ekposisi melalui metode take and give dengan pemanfaatan strategi $3 \mathrm{~W} 2 \mathrm{H}$ pada Kelas X IPA 1 SMA Muhammadiyah 3 Jember?(2) Bagaimanakah hasil belajar siswa dalam menulis teks ekposisi melalui metode take and give dengan pemanfaatan strategi $3 \mathrm{~W} 2 \mathrm{H}$ pada Kelas X IPA 1 SMA Muhammadiyah 3 Jember?

Hasil penelitian sebelum yang menggunakan metode take and give menunjukkan terdapat pengaruh model pembelajaran tipe take and give dengan hasil belajar siswa. Penelitian karya Meda, Wakidi dan Syaiful (2017) menunjukkan bahwa hasil analisis data berada pada kategori kuat dengan koefisien korelasi Eta sebesar $0.72 \mathrm{Hal}$ inilah yang menyebabkan peneliti memilih pembelajaran tipe take and give sebagai metode untuk meningkatkan kemampuan siswa dalam menulis teks ekposisi.

Eksposisi adalah uraian yang bertujuan menjelaskan maksud dan tujuan (KBBI Daring). Sedangkan pengertian menurut Suherli dkk (2016:53) eksposisi adalah uraian berupa 
sajian gagasan berdasarkan sudut pandang tertentu dengan menyertakan alasan-alasan logis yang dapat dibuktikan, dievaluasi, dan diklarifikasi. Eskposisi dapat berbentuk satu paragraf atau beberapa paragraf. Berdasarkan kedua pengertian tersebut, maka teks eksposisi dapat didefinisikan sebagai berikut. Teks eksposisi adalah bahan tertulis untuk dasar memberikan pidato, ceramah, perkuliahan, editorial atau opini berupa sajian gagasan berdasarkan sudut pandang tertentu dengan menyertakan alasan-alasan logis yang dapat dibuktikan, dievaluasi, dan diklarifikasi.

Menurut Suherli dkk (2016:54) teks eskposisi dibentuk dengan tiga bagian atau tiga struktur. Struktur teks eksposisi meliputi: (1) pernyataan pendapat atau tesis, (2) argumentasi, dan (3) penegasan ulang atau reiterasi. Berikut penjelasan ketiga struktur tersebut.

a)Pernyataan Pendapat (Tesis)

Pernyataan pendapat (tesis) adalah bagian pembuka dalam teks ekposisi. Bagian ini berisi pendapat umum yang disampaikan penulis terhadap permasalahan yang diangkat dalam teks eksposisi.

b) Argumentasi

Argumentasi adalah unsur penjelas untuk mendukung tesis yang disampaikan. Argumentasi dapat berupa alasan logis, data hasil temuan, fakta-fakta, bahkan pernyataan para ahli. Argumen yang baik harus mendukung pendapat yang disampaikan penulis atau pembicara.

c)Penegasan Ulang (Reiterasi)

Penegasan ulang (reiterasi) adalah bagian yang bertujuan menegaskan pendapat awal serta menambah rekomendasi atau saran terhadap permasalahan yang diangkat.

Take and Give merupakan bagian dari pendekatan komunikatif. Take and give menitikberatkan penggunaan komunikasi yang baik antara pemberi dan penerima informasi dalam memahami sesuatu (Huda, 2015: 241). Take and give adalah model pembelajaran kooperatif yang diartikan sebagai saling memberi dan saling menerima. Hal penting yang dapat diperoleh dari metode ini adalah siswa menguasai materi melalui kartu, kerjasama secara berpasangan, dan keterampilan berbagi informasi. Metode take and give membuat siswa memahami lebih dalam materi yang disajikan oleh dosen, melatih bekerja sama, menghargai kemampuan orang lain, dan meningkatkan tanggung jawab siswa atas kartu yang dia pegang.

Metode take and give yang diterapkan dalam penguasaan materi tentang menulis teks ekposisi. Metode take and give meliputi delapan langkah. Kedelapan langkah tersebut yaitu: (1) menyiapkan kelas sebagaimana mestinya; (2) dosen menjelaskan materi kurang lebih selama 45 menit; (3) untuk memantapkan penguasaan siswa, tiap siswa diberi kartu warna-warni yang dibaliknya terdapat pertanyaan dan jawaban tentang teks ekposisi; (4) siswa yang memegang kartu berisi pertanyaan mengambil giliran lebih dulu dengan arahan dosen; (5) siswa yang memegang kartu berisi jawaban akan membacakan jawaban atas pertanyaan siswa pasangannya tadi; (6) dosen mengisi kartu kontrol yang berisi daftar pertanyaan dan 
jawaban serta nama pasangan siswa pada setiap pertanyaan dan jawaban; (7) demikian seterusnya sampai tiap peserta dapat saling memberi dan menerima pertanyaan dan jawaban tentang materi teks ekposisi; (8) dosen menyimpulkan materi hasil pembelajaran take and give.

Strategi $3 \mathrm{~W} 2 \mathrm{H}$ adalah cara merumuskan pertanyaan-pertanyaan untuk mendapatkan informasi dari tema yang akan ditulis. Strategi $3 \mathrm{~W} 2 \mathrm{H}$ digunakan untuk membantu siswa menulis teks ekposisi. Strategi $3 \mathrm{~W} 2 \mathrm{H}$ dipilih untuk membantu siswa menggabungkan kegiatan membaca dan menulis untuk mengeksplorasi tema yang akan ditulis dalam sebuah teks ekposisi. Berikut langkah-langkah penerapan strategi $3 \mathrm{~W} 2 \mathrm{H}$.

\section{W1: Apa pertanyaanmu}

Pada langkah pertama ini siswa diminta merumuskan pertanyaan umum (misalnya apa, siapa, kapan, di mana, mengapa, dan bagaimana) dan mengembangkan pertanyaan umum tersebut menjadi sebuah informasi sederhana.

2. W2: Apakah yang sudah kamu ketahui tentang topik itu?

Siswa diminta melengkapi setiap pertanyaan dengan pendapat yang disertai informasi yang relevan. Pada langkah ini siswa diharap aktif mengumpulkan informasi sesuai pengetahuan yang melatarbelakangi suatu topik.

3. W3: Di mana kamu dapat menemukan pemaparan?

Siswa diminta menemukan sumber informasi untuk menjawab pertanyaanpertanyaan tersebut. Sumber informasi dapat diperoleh siswa dengan memanfaatkan telepon seluler yang dimiliki setiap siswa, misalnya Wikipedia, artikel ilmiah, atau artikel populer yang dapat diakses dengan mesin pencari google.

4. H1: Bagaimana kamu merekam ide-idemu?

Siswa menginterpretasikan informasi yang diperoleh untuk diususn menjadi sebuah teks ekposisi. Untuk memudahkan mengorganisasi informasi hasil temuan mereka, siswa diminta membuat bagan, ikhtisar atau catatan kecil.

5. H2: Bagaimana kamu membagi penemuanpenemuanmu?

Siswa menyusun sebuah teks ekposisi dengan memperhatikan tesis, argumentasi, dan reiterasi. Ketiga struktur teks eksposisi tersebut disusun berdasarkan pertanyaan, pendapat, dan informasi yang telah dirumuskan oleh siswa.

Metode Take and Give dengan strategi $3 \mathrm{~W} 2 \mathrm{H}$ digunakan untuk membuat siswa kelas $X$ IPA 1 lebih aktif dalam memahami dan menulis teks ekposisi. Oleh karena itu, diharapkan seluruh siswa di kelas X IPA antusias mengikuti pembelajaran pada materi teks ekposisi, menerima tugas dengan baik, dan menulis teks ekposisi dengan baik dan atas usaha sendiri.

Berdasarkan uraian di atas, peneliti ingin membuktikan hipotesis berikut pada kegiatan PTK ini. Hipotesis tindakan dalam penelitian ini ialah: (1) Penerapan metode take and give dengan pemanfaatan strategi $3 \mathrm{~W} 2 \mathrm{H}$ dapat meningkatkan proses belajar menulis teks eksposisi pada siswa kelas X IPA 1 SMA Muhammadiyah Jember; (2) Penerapan metode take and give dengan pemanfaatan strategi $3 \mathrm{~W} 2 \mathrm{H}$ dapat meningkatkan hasil 
belajar menulis teks eksposisi pada siswa kelas $X$ IPA 1 SMA Muhammadiyah Jember.

\section{METODE PENELITIAN}

Jenis penelitian yang dipilih yaitu jenis Penelitian Tindakan Kelas (PTK). Penelitian tindakan kelas adalah penelitian yang dilakukan oleh pengajar dengan suatu pencermatan kegiatan belajar berupa tindakan untuk memperbaiki, memecahkan masalah yang dihadapi dan meningkatkan praktik pembelajaran di kelas. PTK dilaksanakan oleh pendidik dan pejabat struktural perguruan tinggi (Tampubolon, 2014: 18). Pejabat struktural pergutuan tinggi wajib membelajarkan peserta didik. Pejabat struktural perguruan tinggi dalam penelitian ini adalah Ketua Program Studi Pendidikan Bahasa dan Indonesia FKIP UM Jember atau disebut dosen atau disebut peneliti. Penelitian ini dilakukan oleh dosen dan berkolaborasi dengan guru. Penelitian dilaksanakan berdasarkan hasil pencermatan kondisi di kelas X IPA 1 yang siswanya kurang aktif cenderung pendiam dan asyik sendiri. Dosen bertindak untuk memperbaiki kualitas pembelajaran dengan menggunakan metode take and give yang dikolaborasikan dengan strategi 3W2H.

Desain atau model penelitian yang digunakan dalam penelitian ini adalah model siklus Arikunto. Model siklus Arikunto dimulai dari perencanaan, tindakan, pengamatan dan refleksi.Tahapan dalam penelitian dapat dilihat pada bagan alur PTK pada gambar 1.

Subjek penelitian adalah siswa kelas $X$ IPA 1 yang berjumlah 26 siswa. Kedua puluh enam siswa tersebut terdiri dari 8 laki-laki dan
18 siswa perempuan. Kelas ini dipilih karena di kelas inilah ditemukan siswa-siswa yang tidak aktif dalam pembelajaran, khususnya materi teks eksposisi.

Lokasi penelitian berada di SMA Muhammadiyah 3 Jember yang beralamat di Jalan Mastrip, Kelurahan Sumbersari, Kecamatan Sumbersari, Kabupaten Jember. Lokasi ini dipilih karena sekolah tersebut menjadi mitra dari setiap kegiatan di FKIP UM Jember. Sehubungan dengan program Penugasan Dosen di Sekolah, maka FKIP ingin memberikan sumbangsih yang positif terhadap kualitas perbaikan pembelajaran di sekolah mitra ini.

Penelitian ini dilaksanakan dengan prosedur berdaur, yakni perencanaaan, pelaksanaan, observasi, dan refleksi begitu seterusnya sampai dirasakan sudah ada perbaikan pembelajaran (Ismawati, 2012: 51). Prosedur penelitian meliputi empat tahap, yaitu perencanaan tindakan, pelaksanaan tindakan, pengamatan, dan refleksi.Keempat tahapan tersebut dirangkai dalam sebuah siklus. Apabila melalui kegiatan refleksi sudah diketahui kekurangan atau permasalahan pada siklus I, peneliti bersama guru melanjutkan penelitian pada siklus II. Berikut kempat tahap dalam prosedur penelitian.

1) Studi Pendahuluan

Studi pendahuluan dilaksanakan sebagai tahap identifikasi awal yang bertujuan mengetahui permasalahan dalam pembelajaran menulis teks eksposisi di kelas $X$ IPA 1 SMA Muhammadiyah Jember. Pada tahap ini, guru dan peneliti secara kolaboratif merasakan dan mengidentifikasi masalah. Kemudian, guru dan peneliti merumuskan 
dugaan awal tentang tindakan yang akan diambil untuk memecahkan masalah siswa dalam menulis teks eksposisi.

2) Perencanaan Tindakan

Perencanaan tindakan disusun berdasarkan program dan jadwal yang telah disusun bersama guru, yang disesuaikan dengan kondisi di sekolah. Selain menyusun Rencana Pelaksanaan Pembelajaran (RPP), peneliti bersama guru juga menyusun instrumen pengumpulan data yang akan digunakan dalam pengamatan terhadap proses pembelajaran, serta pedoman penyekoran hasil tes siswa untuk mengetahui kemampuan siswa.

3) Pelaksanaan Tindakan

Pada tahap ini kegiatan yang dilaksanakan ialah melaksanakan kegiatan pembelajaran seperti yang telah direncanakan, yaitu peneliti menerapkan metode take and give dan strategi $3 \mathrm{~W} 2 \mathrm{H}$ dalam pembelajaran pada materi teks eksposisi.

\section{4) Pengamatan}

Pada tahap ini dilakukan pengamatan dan pencatatan terhadap semua hal yang terjadi selama proses pembelajaran berlangsung. Fokus pengamatan ialah pada kegiatan siswa dan kegiatan dosen.

5) Refleksi

Tahap ini dilakukan untuk mengetahui apakah tujuan dalam pembelajaran sudah tercapai atau sebaliknya. Berdasarkan hasil belajar dan hasil pengamatan, peneliti bersama guru melakukan analisis, penafsiran, dan penyimpulan terhadap kegiatan yang dilakukan dikelas, baik kegiatan siswa maupun kegiatan dosen. Siklus 2 dilakukan apabila hasil yang diperoleh pada siklus 1 tidak memenuhi target pencapaian yang diinginkan.
Pelaksanaan siklus 2 didahului dengan perbaikan berdasarkan hasil yang diperoleh pada siklus 1.

Kriteria kesuksesan yang digunakan adalah dengan menggunakan skor hasil tes yang menggambarkan prestasi akademik, keaktifan, dan partisipasi siswa. Penelitian tindakan kelas sukses atau berhasil apabila nilai siswa lebih besar atau sama dengan 87, dan secara klaksikal jumlah siswa yang mendapat nilai 87 mencapai 19-21 siswa.

Instrumen pengumpulan data yang digunakan dalam penelitian ini meliputi instrumen tes, lembar pengamatan, dan angket. Berikut penjelasan ketiga instrument tersebut.

1) Instrumen Tes

Hasil tes dijadikan ukuran kinerja dalam menguasai materi dan mengetahui kelemahan siswa (Ismawati, 2012: 50). Instrumen tes berupa soal menulis teks ekposisi Soal dibuat sendiri oleh guru untuk mengukur kinerja siswa dalam menguasai materi teks ekposisi.

2) Lembar Pengamatan

Catatan lapangan digunakan untuk memantau pelaksanaan pembelajaran dalam PTK (Ngadiman, 2014: 264-265). Catatan lapangan yang digunakan dalam penelitian berupa lembar pengamatan atau check list yang berisi daftar dari semua aspek yang akan diobservasi, meliputi kegiatan pengajar dan kegiatan siswa.

3) Angket

Angket terdiri atas serangkaian pertanyaan tertulis yang memerlukan jawaban tertulis (Ngadiman, 2014: 266). Angket yang digunakan dalam penelitian ini adalah angket tertutup yang meminta responden untuk memilih kalimat yang paling dekat dengan 
pendapat, perasaan, penilaian, dan posisi mereka terhadap pembelajaran menulis teks ekposisi.

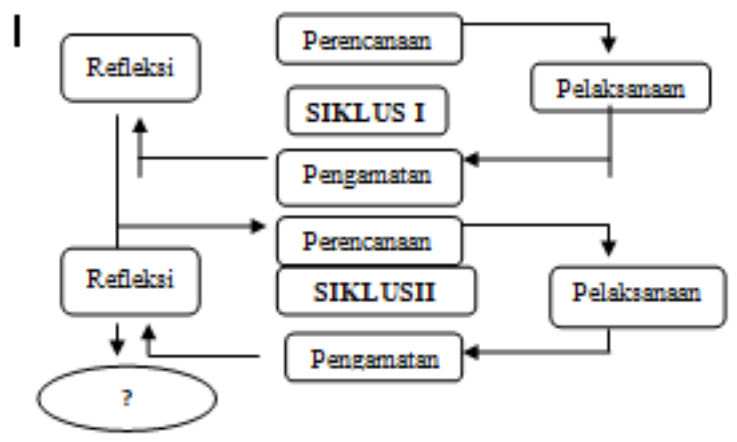

Bagan 1 Siklus Penelitian Tindakan kelas (Sumber: Arikunto, 2010:137)

\section{PEMBAHASAN}

Pembelajaran menulis teks ekposisi pada siswa kelas X IPA 1 SMA Muhammadiyah Jember ini dilaksanakan pada tiga kali pertemuan, satu pertemuan dilakukan untuk pretes (tanggal 27 Agustus 2018) sedangkan dua kali pertemuan digunakan untuk kegiatan siklus I (tanggal 10 September 2018) dan siklus II (tanggal 11 Oktober 2018).

Masalah yang diangkat dalam PTK merupakan masalah yang dihayati guru dalam praktik pembelajaran yang dikelolanya (Syamsuddin dan Damaianti, 2015: 235). Masalah yang dirasakan adalah siswa kurang komunikatif dalam merespon penjelasan guru tentang materi menulis teks ekposisi. Kemudian, guru dan peneliti mendiskusikan dan merumuskan pendekatan komunikatif berupa take and give.

Perencanaan tindakan dilakukan untuk mempersiapkan segala seuatu yang dibutuhkan dalam PTK agar menghasilkan dampak seperti yang diharapkan (Syamsuddin dan Damaianti, 2015: 237).Perencanaan tindakan dilakukan dengan memilih model siklus mudah dipahamai dan diikuti; menyiapkan RPP, instrumen pengumpulan data dan pedoman penyekoran; menyiapkan kondisi siswa, materi menulis teks ekposisi, dan kartu take and give disiapkan dengan tepat.

Pelaksanaan tindakan dilakukan peneliti dan guru dengan langkah berikut. Peneliti menyampaikan materi menulis teks ekposisi dengan memanfaatkan power point, LCD, dan papan tulis putih. Siswa mencari jawaban atau pertanyaan dari informasi pada kartu yang dipegangnya. Peneliti memastikan kebenaran dari informasi yang diberi dan diterima oleh siswa. Selanjutnya, peneliti menjelaskan perintah penulisan teks ekposisi kepada siswa. Siswa mengerjakan secara mandiri.

Pengamatan dilakukan oleh guru terhadap aktivitas peneliti saat mengajar dan kegiatan para siswa selama mengikuti pembelajaran. Hasil pengamatan guru direkam pada lembar pengamatan.

Berdasarkan diskusi antara peneliti dan guru tentang pelaksanaan pembelajaran pada siklus I, ditemukan beberapa hal berikut. Nilai rata-rata dari hasil belajar siswa belum mencapai peningkatan yang signifikan. Siswa belum menunjukkan antusias dalam memanfaatkan kartu dalam pendekatan take and give. Peneliti belum seratus persen menerapkan take and give untuk mengajak siswa lebih komunikatif dalam menguasai materi menulis teks eksposisi.

Berdasarkan hasil refleksi tersebut, dilakukan siklus kedua untuk perbaikan pembelajaran. Maka diulanglah seluruh 
rangkaian kegiatan seperti yang dilakukan pada siklus I dengan penambahan strategi $3 \mathrm{~W} 2 \mathrm{H}$ dan pemantapan penggunaan metode take and give.

Pada siklus II ini, penggunaan kartu pada metode take and give dikontrol oleh peneliti lewat kartu kontrol sehingga peneliti dapat langsung memberi umpan balik atas temuan informasi yang dilakukan siswa. Saat memberikan perintah menulis teks ekposisi, peneliti menerapkan strategi $3 \mathrm{~W} 2 \mathrm{H}$. Strategi ini membuat siswa aktif bekerja dan antusias membuka sumber informasi dengan telepon seluler masing-masing. Kemudian siswa menuangkan ide dalam bentuk paragraf eksposisi.

Hasil pengamatan dan koreksi paragraf eksposisi pada siklus II menunjukkan bahwa nilai rata-rata siswa meningkat dan memenuhi kriteria kesuksesan. Dengan demikian penelitian tindakan kelas telah berhasil dilakukan dengan dua siklus.

Berdasarkan hasil penelitian terdapat peningkatan proses belajar siswa yang terjadi dari prasiklus, siklus I, dan siklus II. Peningkatan tersebut dapatmembuktikan hipotesis tindakan. Hipotesis tindakan dalam penelitian ini ialah: (1) Penerapan metode take and givedengan pemanfaatan strategi $3 \mathrm{~W} 2 \mathrm{H}$ dapat meningkatkan proses belajar menulis teks eksposisi pada siswa kelas X IPA 1 SMA Muhammadiyah Jember; (2) Penerapan metode take and givedengan pemanfaatan strategi $3 \mathrm{~W} 2 \mathrm{H}$ dapat meningkatkan hasil belajar menulis teks eksposisi pada siswa kelas $X$ IPA 1 SMA Muhammadiyah Jember. Peningkatan proses pembelajaran dan penerapan metode take and give dengan pemanfaatan strategi $3 \mathrm{~W} 2 \mathrm{H}$ dapat dilihat pada tabel 1,2, dan 3 .

Tabel 1 Hasil Pengamatan Kegiatan Pembelajaran Dosen

\begin{tabular}{|l|l|l|l|l|}
\hline No & $\begin{array}{l}\text { Aspek yang } \\
\text { Diamati }\end{array}$ & Pretes & Siklus I & $\begin{array}{l}\text { Siklus } \\
\text { II }\end{array}$ \\
\hline 1 & $\begin{array}{l}\text { Persiapan } \\
\text { dosen }\end{array}$ & 2,33 & 4 & 4 \\
\hline 2 & $\begin{array}{l}\text { Kegiatan } \\
\text { dosen }\end{array}$ & 2,83 & 4 & 4 \\
\hline 3 & $\begin{array}{l}\text { Komunikasi } \\
\text { dosen } \\
\text { dengan Siswa }\end{array}$ & 3,33 & 4 & 4 \\
\hline 4 & $\begin{array}{l}\text { Waktu yang } \\
\text { disediakan }\end{array}$ & 2 & 3 & 4 \\
\hline 5 & $\begin{array}{l}\text { Kegiatan } \\
\text { secara umum }\end{array}$ & 3 & 3,2 & 4 \\
\hline & Jumlah & $\mathbf{1 3 , 4 9}$ & $\mathbf{1 8 , 2}$ & $\mathbf{2 0}$ \\
\hline & Rata-rata & $\mathbf{2 , 6 9 8}$ & $\mathbf{3 , 6 4}$ & $\mathbf{4}$ \\
\hline & $\begin{array}{l}\text { Jumlah } \\
\text { Peningkatan } \\
\text { Rata-rata }\end{array}$ & $\mathbf{0 , 9 5}$ & $\mathbf{0 , 3 6}$ \\
\hline
\end{tabular}

Peningkatan proses pembelajaran dosen tampak pada tabel 1. Dari tabel 1 dapat dijelaskan bahwa kegiatan dari pretes ke siklus I menunjukkan peningkatan sebesar 0,95. Sedangkan dari siklus I ke siklus II yang dilakukan menunjukkan peningkatan sebesar 0,36 . Hal ini dapat dilihat dari jumlah nilai ratarata yang diperoleh yaitu mengalami peningkatan dari pretes sebesar 2,69 menjadi 3,64 pada siklus I, dan meningkat lagi pada siklus II sebesar 4 .

Tabel 2 Hasil Pengamatan Kegiatan Pembelajaran Siswa

\begin{tabular}{|l|l|l|l|l|}
\hline No & \multicolumn{1}{|c|}{$\begin{array}{c}\text { Aspek yang } \\
\text { Diamati }\end{array}$} & Pretes & Siklus I & Siklus II \\
\hline 1 & Kondisi Siswa & 3 & 3 & 4,66 \\
\hline 2 & Kegiatan Siswa & 2 & 3,2 & 4,8 \\
\hline 3 & $\begin{array}{l}\text { Komunikasi Siswa } \\
\text { dengan Dosen }\end{array}$ & 2,25 & 3,75 & 4,5 \\
\hline 4 & Hasil Kerja Siswa & 2 & 4 & 5 \\
\hline
\end{tabular}




\begin{tabular}{|l|l|l|l|l|}
\hline 5 & $\begin{array}{l}\text { Waktu yang } \\
\text { Disediakan }\end{array}$ & $\mathbf{2 , 5}$ & 2,5 & 4 \\
\hline 6 & $\begin{array}{l}\text { Kegiatan Secara } \\
\text { Umum }\end{array}$ & $\mathbf{2 , 5}$ & $\mathbf{4}$ & $\mathbf{4 , 7 5}$ \\
\hline & Jumlah & $\mathbf{1 4 , 2 5}$ & $\mathbf{2 0 , 4 5}$ & $\mathbf{2 7 , 7 1}$ \\
\hline & $\begin{array}{l}\text { Rata-rata } \\
\text { Jumlah } \\
\text { Peningkatan } \\
\text { Rata-rata }\end{array}$ & $\mathbf{2 , 3 7 5}$ & $\mathbf{3 , 4 0 8}$ & $\mathbf{4 , 6 1 8}$ \\
\hline
\end{tabular}

Pengamatan terhadap kegiatan belajar siswa selama kegiatan pembelajaran berlangsung dapat dilihat pada tabel 2. Dari tabel 2 dapat dipahami bahwa kegiatan belajar siswa pada pretes ke siklus I menunjukkan peningkatan sebesar 1,03. Sedangkan dari siklus I ke siklus II kegiatan belajar yang dilakukan oleh siswa menunjukkan peningkatan sebesar 1,21. Hal ini dapat dilihat dari jumlah nilai rata-rata yang mengalami peningkatan yaitu dari 2,375 pada pretes menjadi 3,408pada siklus I, dan meningkat lagi pada siklus II sebesar 4,618.

Tabel 3 Hasil Belajar Siswa

\begin{tabular}{|c|c|c|c|c|c|}
\hline \multirow{2}{*}{ No } & \multirow{2}{*}{ No Pokok } & \multirow{2}{*}{ Nama } & \multicolumn{3}{|c|}{ Nilai } \\
\hline & & & Pretes & Siklus 1 & Siklus 2 \\
\hline 1 & 251SB1819 & Alya ramadhania Hafizha Hehaenvi & 100 & 100 & 100 \\
\hline 2 & 013SB1819 & Aprillianur Aisyah & 77 & 93 & 93 \\
\hline 3 & 012SB1819 & Arsyandaraissa Indragiy Firjatullah & 100 & 100 & 93 \\
\hline 4 & 244SB1819 & Daffafirmansyah & 90 & 90 & 93 \\
\hline 6 & 034SB1819 & Deva Octa Vinona & 77 & 83 & 97 \\
\hline 7 & 250SB1819 & Dwiki Haykhal Satriawan & 83 & 87 & 100 \\
\hline 8 & 255SB1819 & Fadilah Arifah Henidiah (Dela) & 93 & 97 & 100 \\
\hline 9 & 008SB1819 & Fazareta Navia & 87 & 90 & 83 \\
\hline 10 & 002SB1819 & Fhanaya Ramadhaniar Subagyo & 97 & 80 & 93 \\
\hline 11 & 200SB1819 & Halimatus sa'Diyah (Lina) & 83 & 77 & 77 \\
\hline 12 & 344SB1819 & Hasan Bayakub & 83 & 93 & 80 \\
\hline 14 & 060SB1819 & Ilham Ramadhani subali & 80 & 87 & 83 \\
\hline 15 & 335SB1819 & M. Sahil Maulana & 73 & 67 & 93 \\
\hline 17 & 204SB1819 & Nabila Davina Shafaaura Laila R & 70 & 80 & 87 \\
\hline 18 & 123SB1819 & Nicky Ganang Putra Reynaldi V & 16 & 90 & 97 \\
\hline 19 & 067SB1819 & Nisrinasalma (Ines) & 16 & 97 & 97 \\
\hline 20 & 063SB1819 & Pyvico Fadera Gardy & 73 & 80 & 90 \\
\hline 21 & 076SB1819 & Rafliakbar Utama & 80 & 87 & 87 \\
\hline 23 & 292SB1819 & Rizqihidayatus Soleha (Kiki) & 83 & 87 & 97 \\
\hline 24 & 147SB1819 & Salmazada Rezita Dewi & 77 & 100 & 100 \\
\hline 25 & 295SB1819 & Salsabilatul maghfiroh Syafni & 16 & 97 & 90 \\
\hline \multirow[t]{3}{*}{26} & 032SB1819 & Shafa'Na Zain Setiawati & 87 & 87 & 83 \\
\hline & Jumlah & & 1747 & 2083 & 2196 \\
\hline & Rata-rata & & 83,19 & 99,19 & 104,57 \\
\hline
\end{tabular}

Peningkatan hasil belajar siswa pada kegiatan menulis teks ekposisi dapat dilihat pada tabel 3. Dalam daftar di atas tercatat 26 siswa. Namun, yang dihitung jumlah dan rataratanya hanya 21 siswa. Nomor absen 5, 13, 16, 22, 27 tidak termasuk dihitung karena tidak mengikuti seluruh rangkaian siklus dengan lengkap.

Pada tabel 3 menunjukkan bahwa terjadi peningkatan hasil belajar pada pembelajaran menulis teks ekposisi melalui metode take and give dengan pemanfaatan 
strategi 3W2H. Dari tabel tersebut menunjukkan pada tahap pretes nilai ratarata siswa masih mencapai nilai 83,19. Selanjutnya dilakukan tindakan perbaikan pada siklus I. Hasil belajar siswa pada siklus I meningkat dengan hasil belajar mencapai 99,19 . Pada siklus II rata-rata hasil belajar siswa meningkat lagi sehingga mencapai $104,57$.

\section{SIMPULAN}

Berdasarkan hasil penelitian dan pembahasan menulis teks ekposisi dapat disimpulkan proses belajar siswa dan hasil belajar siswa. Proses belajar siswa pada pretes ke siklus I menunjukkan peningkatan sebesar 1,03. Sedangkan dari siklus I ke siklus II kegiatan belajar yang dilakukan oleh siswa menunjukkan peningkatan sebesar 1,21 . Hal ini dapat dilihat dari jumlah nilai rata-rata yang mengalami peningkatan yaitu dari 2,375 pada pretes menjadi 3,408 pada siklus I, dan meningkat lagi pada siklus II sebesar 4,618. Hasil belajar siswa pada kegiatan menulis teks ekposisi menunjukkan pada tahap pretes nilai rata-rata siswa masih mencapai nilai 83,19. Selanjutnya dilakukan tindakan perbaikan pada siklus I. Hasil belajar siswa pada siklus I meningkat dengan hasil belajar mencapai 99,19 . Pada siklus II rata-rata hasil belajar siswa meningkat lagi sehingga mencapai 104,57 .

\section{DAFTAR RUJUKAN}

Arikunto, S. (2010). Prosedur Penelitian Suatu

Pendekatan Praktik. Jakarta: Rineka Cipta.
Badan Pengembangan dan Pembinaan Bahasa. (2016). KBBI Daring. Kementerian Pendidikan dan Kebudayaan Republik Indonesia. (online) https://kbbi.kemdikbud.go.id, diakses 9 Oktober 2018

Huda, M. (2015). Model-Model Pengajaran dan Pembelajaran: Isu-Isu Metodis Paradigmatis. Yogyakarta: Pustaka Pelajar

Ismawati, E. (2012). Metode Penelitian Pendidikan Bahasa dan Sastra. Yogyakarta: Ombak

Meda, L. Y., Wakidi, dan Syaiful M. (2017). Pengaruh Model Pembelajaran Take and Give terhadap Hasil Belajar SiswaKelas X. Jurnal FKIP Unila. (online)

https://jurnal.fkip.unila.ac.iddiakses 9 Oktober 2018

Ngadiman, A. (2014). Aplikasi Penelitian Tindakan Kelas. Dalam Modul Pelatihan Applied Approach (AA) oleh Tim Fasilitator Pelatihan Pekerti-AA Kopertis Wilayah VII, Koordinator Perguruan Tinggi Swasta Wilayah VII pada 9-13 Mei 2018 di Universitas Muhammadiyah Jember

Suherli dkk. (2016). Bahasa Indonesia. Jakarta : Kementerian Pendidikan dan Kebudayaan

Syamsi, K. (Tanpa tahun). Inovasi Model Pembelajaran Bahasa Indonesia. (Online), https://staffnew.uny.ac.id, diakses 9 Oktober 2018 
Yerry Mijianti, Endah Puji Puspitosari. Meningkatkan Keterampilan....

Halaman 149-159 Jurnal Belajar Bahasa, ISSN 2502-5864, E-ISSN 2503-0329

Volume 4, No. 1, Februari 2019

Syamsuddin dan Damaianti, V.S. (2015).

Metode Penelitian Pendidikan Bahasa.

Bandung: Remaja Rosdakarya.

Tampubolon, S. (2014). Penelitian Tindakan

Kelas sebagai Pengembangan Profesi

Pendidik dan Keilmuan. Jakarta:

Erlangga. 